\title{
Concurrent activity of anammox and denitrifying bacteria in the Black Sea
}

\author{
John B. Kirkpatrick ${ }^{1,2 *}$, Clara A. Fuchsman ${ }^{1}$, Evgeniy Yakushev ${ }^{3}$, James T. Staley and \\ James W. Murray ${ }^{1}$ \\ ${ }^{1}$ School of Oceanography, University of Washington, Seattle, WA, USA \\ ${ }^{2}$ Graduate School of Oceanography and Center for Dark Energy Biosphere Investigations, University of Rhode Island, Narragansett, RI, USA \\ ${ }^{3}$ Norwegian Institute for Water Research, Oslo, Norway \\ ${ }^{4}$ Department of Microbiology, University of Washington, Seattle, WA, USA
}

\section{Edited by:}

Bess B. Ward, Princeton University, USA

\section{Reviewed by:}

Bonnie X. Chang, Princeton

University, USA

Mark Trimmer, Queen Mary

University of London, UK

${ }^{*}$ Correspondence:

John B. Kirkpatrick, Graduate School Oceanography, University of Rhode Island, Narragansett Bay Campus,

South Ferry Road, Narragansett,

RI, 02882, USA.

e-mail: jbk@gso.uri.edu
After the discovery of ANaerobic AMMonium OXidation (anammox) in the environment, the role of heterotrophic denitrification as the main marine pathway for fixed $\mathrm{N}$ loss has been questioned. A 3 part, 15 month time series investigating nitrite reductase (nirS) mRNA transcripts at a single location in the Black Sea was conducted in order to better understand the activity of anammox and denitrifying bacteria. Here we show that both of these groups were active, as well as being concurrent in the lower suboxic zone over this time span. Their distributions, however, differed in that only expression of denitrification-type nirS was seen in the upper suboxic zone, where geochemistry was variable. Depth profiles covering the suboxic zone showed that the four groups of anammox-type sequences were expressed consistently in the lower suboxic zone, and were consistent with anammox $16 \mathrm{~S}$ rDNA gene profiles. By contrast, denitrifier-type nirS sequence groups were mixed; some groups exhibited consistent expression in the lower suboxic zone, while others appeared less consistent. Co-occurrence of both anammox and denitrifier expression was common and ongoing. Both types of transcripts were also found in samples with low concentrations of sulfide $(>2 \mu \mathrm{M})$. Six major groups of denitrifier-type nirS transcripts were identified, and several groups of denitrifier-type nirS transcripts were closely related to sequences from the Baltic Sea. An increase in denitrifier-type nirS transcript diversity and depth range in October 2007 corresponded to a small increase in mixed layer net community productivity (NCP) as measured by $\mathrm{O}_{2} / \mathrm{Ar}$ gas ratios, as well as to an increase in $\mathrm{N}_{2}$ concentrations in the suboxic zone. Taken together, the variations in expression patterns between anammox and denitrification provide one possible explanation as to how near instantaneous rate measurements, such as isotope spike experiments, may regularly detect anammox activity but underreport denitrification.

Keywords: anammox, denitrification, Black Sea, nirS, nitrogen, gene expression

\section{INTRODUCTION}

Fixed nitrogen loss from marine systems balances $\mathrm{N}$ fixation, thereby exerting a long-term control over primary productivity and therefore climate (Altabet et al., 1995, 1999; Ganeshram et al., 1995), as well as anthropogenic influences. Loss of fixed $\mathrm{N}$ occurs via two microbial pathways: denitrification and the more recently discovered anammox process (ANaerobic AMMonium OXidation). While both require nitrite $\left(\mathrm{NO}_{2}^{-}\right)$, heterotrophic denitrification is reliant on organic $\mathrm{C}$ while anammox requires ammonium $\left(\mathrm{NH}_{4}^{+}\right)$. Since the discovery of environmental anammox in marine sediments (Thamdrup and Dalsgaard, 2002) and the water column (Dalsgaard et al., 2003; Kuypers et al., 2003), many groups have debated the relative role of these two processes in the environment. Anammox organisms have now been documented in many water column marine oxygen minimum zones (OMZs), and isotope labeling experiments have even shown in some cases a complete lack of denitrification (Schmid et al., 2007; Jensen et al., 2008; Lam et al., 2009). Other labeling studies have pointed towards a dominant contribution from denitrifiers (Ward et al., 2009), while DNA-based methods have suggested the potential for considerable variation in levels of heterotrophic denitrification (Jayakumar et al., 2009a). Conclusions regarding the dominance of one pathway over the other have thus been varied and conflicting (Lam et al., 2007; Schmid et al., 2007; Fuchsman et al., 2008; Lam et al., 2009; Ward et al., 2009; Bulow et al., 2010; Jensen et al., 2011). It has also been shown that it is possible to construct an $\mathrm{N}$ cycle where the role of heterotrophic denitrification is entirely replaced by Dissimilatory Nitrite Reduction to Ammonium (DNRA) coupled with anammox (Lam et al., 2009; Jensen et al., 2011).

The Black Sea is well suited for investigations of these processes, as it is permanently anoxic at depth and contains a well-defined suboxic zone $\left(\mathrm{O}_{2}<10 \mu \mathrm{M}\right.$, no detectable $\mathrm{H}_{2} \mathrm{~S}$; Figure 1) sandwiched between shallow oxic and deeper sulfidic waters (Murray et al., 1995). Nonetheless, there has been no consensus there as to the relative contributions of anammox and 


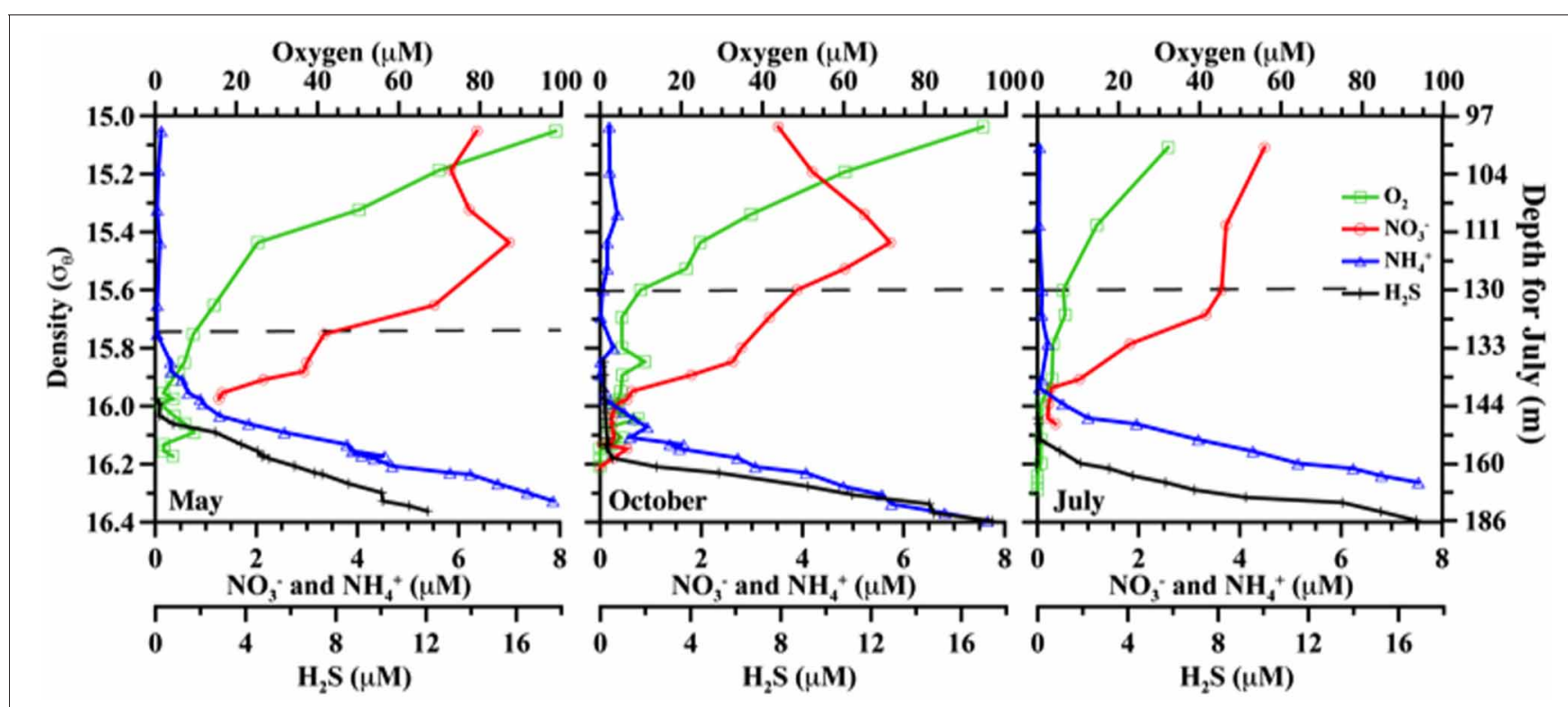

FIGURE 1 | Comparative chemical profiles for the three different cruises. Markers indicate discrete samples. Plots are versus density as absolute depths are less consistent. For reference, July 2008 also includes absolute depth in $\mathrm{m}$, but note this measure only applies to the right panel. From left to right, panels are for May 2007; October 2007; and July 2008. Horizontal dashed lines indicate the upper boundary of the suboxic zone $\left(\mathrm{O}_{2}=10 \mu \mathrm{M}\right)$. denitrification to $\mathrm{N}_{2}$ production (Lam et al., 2007; Fuchsman et al., 2008; Jensen et al., 2008). Some incubation experiments with Black Sea water have shown the absence of denitrification activity (Lam et al., 2007). However, the presence of both denitrifying and anammox bacteria in the Black Sea's suboxic zone have also been documented (Kirkpatrick et al., 2006; Oakley et al., 2007). In order to better understand the in situ activity of these organisms and its variability, we investigated transcription of metabolic genes, as a proxy for bacterial activity, from three different cruises in different seasons.

\section{MATERIALS AND METHODS}

Field sampling was conducted in the northeastern Black Sea at $44^{\circ} 25^{\prime} \mathrm{N}, 37^{\circ} 30^{\prime} \mathrm{E}$, onboard the $R / V$ Akvanavt and $R / V$ Ashamba (mean water depth $>1000 \mathrm{~m}$ ), for three time points: May 2007, October 2007, and July 2008. Data is graphed versus potential density $\left(\sigma_{\theta}, \mathrm{kg} \mathrm{m}^{-3}\right)$, measured by SeaBird CTD package attached to the sampling rosette. Density was used to take into account spatial and temporal effects, which may alter the absolute depth of a feature in meters. For example, the oxycline may appear tens of meters shallower or deeper at different times and/or stations, but can be consistently found at the same density range (Murray et al., 1995). Samples were taken for the suboxic zone, roughly $15.6 \leq \sigma_{\theta} \leq 16.1$ (Figure 1; includes July 2008 depth comparison).

\section{NUTRIENTS, DISSOLVED GASES, AND PRODUCTIVITY}

Dissolved oxygen and hydrogen sulfide were measured onshore the night after daytime sampling, using standard techniques (Grasshoff et al., 1983). Nutrients were also measured $\left(\mathrm{NO}_{3}^{-}\right.$, $\mathrm{NO}_{2}^{-}, \mathrm{NH}_{4}^{+}$), with conventional chemical techniques and utilizing an autoanalyzer (Fuchsman et al., 2008). Dissolved gases were collected in evacuated $250 \mathrm{~mL}$ glass cylinders with $\mathrm{HgCl}_{2}$ pre-added, transported to the University of Washington, and measured by a Finnegan Delta XL isotope ratio mass spectrometer as per Fuchsman et al. (2008) and Emerson et al. (1999). A known amount of ${ }^{36} \mathrm{Ar}$ was added to the samples (Nicholson et al., 2010). $\delta^{18} \mathrm{O}-\mathrm{O}_{2}$ values were corrected for addition of ${ }^{36} \mathrm{Ar}$. $\delta^{18} \mathrm{O}-\mathrm{H}_{2} \mathrm{O}$ was measured using an automated Micromass 903 mass spectrometer with $\mathrm{CO}_{2}$ equilibration system at the Quaternary Research Center, University of Washington. Net community productivity (NCP) calculations based on $\mathrm{O}_{2} / \mathrm{Ar}$ were calculated as per equation (2) of Stanley et al. (2010);

$$
\mathrm{NCP}=\Delta\left(\mathrm{O}_{2} / \mathrm{Ar}\right)\left[\mathrm{O}_{2}\right]_{\mathrm{eq}} \rho \mathrm{k}
$$

where $\left[\mathrm{O}_{2}\right]_{\text {eq }}$ is $\mathrm{O}_{2}$ equilibrium concentration (calculated from CTD temperature and salinity data), $\rho$ is the measured density from the CTD, and $\mathrm{k}$ is the gas transfer velocity. Gas exchange parameters were estimated via the parameterizations of Nightingale et al. (2000), using 14 day averaged QuikSCAT wind products. This calculation assumes a well-mixed layer, negligible impact from advection or cross-diapycnal mixing (upwelling), and a steady state system.

\section{RNA SAMPLING AND ANALYSIS}

Different versions of nitrite reductase (nirS) mRNA transcripts corresponding to denitrification and anammox organisms [specifically, "Candidatus Scalindua"-type (Lam et al., 2009)] were extracted, reverse transcribed, amplified and sequenced. Samples for RNA analysis were taken every 0.1 density level from $\sigma_{\theta}=15.5$ to 16.1 , filtered directly from Niskin bottles onto $0.2 \mu \mathrm{m}$ Millipore Sterivex ${ }^{\mathrm{TM}}$ filters, and fixed with RNALater ${ }^{\circledR}$ within $30 \mathrm{~min}$ of the start of filtration. October 2007 was unusual in that opportunistic RNA sampling extended deeper, to $\sigma_{\theta}=16.3$. Filters were incubated for $\sim 1 \mathrm{~h}$, frozen, shipped 
on dry ice to the University of Washington, and ultimately stored at $-80^{\circ} \mathrm{C}$. RNA extraction was conducted similar to Poretsky et al. (2005), and reverse-transcribed with random primers using the Fermentas Maxima ${ }^{\circledR}$ kit. Amplification of Scalindua-type nirS was performed with primers Scnir372F and Scnir845R (Lam et al., 2009). For conventional nirS several primer sets were tried (Braker et al., 1998; Michotey et al., 2000; Throbäck et al., 2004; see discussion). The primary results presented here are the nirS1F/6R primers of Braker et al. (1998) amplified as per Santoro et al. (2006) but using Fermentas DreamTaq $^{\mathrm{TM}} 2 \mathrm{x}$ Mastermix with BSA added to $1 \mathrm{x}$ concentration, because it returned nirS type sequences for the largest number of samples. Attempts were also made to amplify different version of nitrite reductase (nirK) for all samples, but because amplification was at best erratic, and failed outright in the majority of cases, those results are not considered here. Scalindua-type products, uniformly single-banded, were cleaned with a Qiagen PCR Clean-up Kit, while other nirS products were commonly multi-banded and therefore gel-purified (Fermentas GeneJet $^{\mathrm{TM}}$ Gel Purification Kit). Cloning was conducted with the StrataClone PCR Cloning Kit, and sequenced at the HighThroughput Genomics Unit (www.htseq.org). Sequences were hand-checked and amino acid translation was performed with Transeq (European Bioinformatics Institute), related protein sequences added for reference from GenBank (National Center for Biotechnology Information), and alignments performed with ClustalX. Bootstrapped data sets (Phylip's seqboot, 100 replicates) were analyzed for maximum likelihood phylogeny with Phylip (Felsenstein, 2005), and consensus tree branch lengths subsequently determined via protein maximum likelihood (JTT algorithm; Jones et al., 1992). Final tree visualization was accomplished using the program FigTree (http://tree.bio.ed. ac.uk/). Genbank accession numbers are JX102246-JX102470.

\section{TRFLP}

DNA was extracted using a combination of standard freeze-thaw and enzymatic lysis methods, followed by phenol-chloroform extraction and spin-column purification (Qiagen) (Fuchsman et al., 2012). Amplification was obtained using Planctomycetes primers 58F (labeled) and 926R (Wang et al., 2002). PCR products were amplified for 30 cycles at $60^{\circ} \mathrm{C}$ (Fuchsman et al., 2012). Column purified PCR products were digested separately overnight with restriction enzymes HaeIII, Hpy1881, MspI, and immediately precipitated with ethanol. Fragment analysis was performed on a MegaBACE 1000 apparatus (Molecular Dynamics) at the University of Washington Marine Molecular Biotechnology Laboratory. Electrophoretic profiles were visualized with Dax software (Van Mierlo Software Consultancy, The Netherlands). TRFLP profiles were normalized downward by total peak height. Scalindua was identified as peak 236 using HaeIII, peak 530 using HpyI881, and peak 260 using MspI.

\section{RESULTS}

Nutrients $\left(\mathrm{O}_{2}, \mathrm{H}_{2} \mathrm{~S}, \mathrm{NO}_{3}^{-}, \mathrm{NH}_{4}^{+}\right)$are given in Figure 1. Oxygen penetration was deepest in May 2007 and shallowest in July 2008, affecting the apparent range of the suboxic zone (defined as $\mathrm{O}_{2}<$ $10 \mu \mathrm{M}, \mathrm{H}_{2} \mathrm{~S}$ undetectable; appx. $\left.15.7 \leq \sigma_{\theta} \leq 16.1\right)$. Nitrate concentrations were highest at the top of the suboxic zone ( $\max$ between 4.5 and $7 \mu \mathrm{M}$ ), but nitrate was detectable until at least $\sigma_{\theta}=16.0$. Nitrite was below $0.1 \mu \mathrm{M}$ for all seasons, with a small peak around in the suboxic zone and migrating slightly in a similar fashion to oxygen (Figure 2). Ammonium concentrations

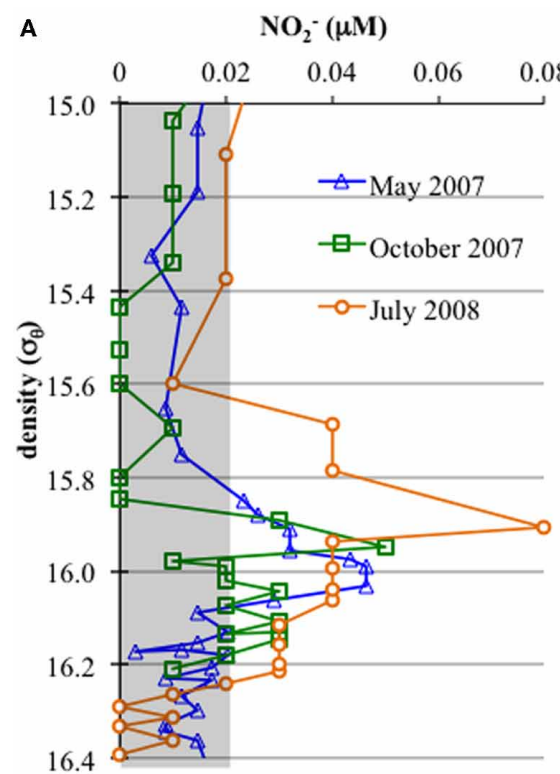

FIGURE 2 | Left: $\mathrm{NO}_{2}^{-}$concentrations, with a gray box indicating values at or below detection limit. Right: First, $\mathrm{N}_{2}$ supersaturation (from $\mathrm{N}_{2} /$ Ar ratio compared to calculated values for saturation); $\mathrm{N}_{2}$ is produced in situ in the lower suboxic zone. To the right, detection of gene transcripts: " $A$ " indicates

\section{$\% \mathrm{~N}_{2}$ supersaturation Transcripts amplified and sequenced (see caption):}

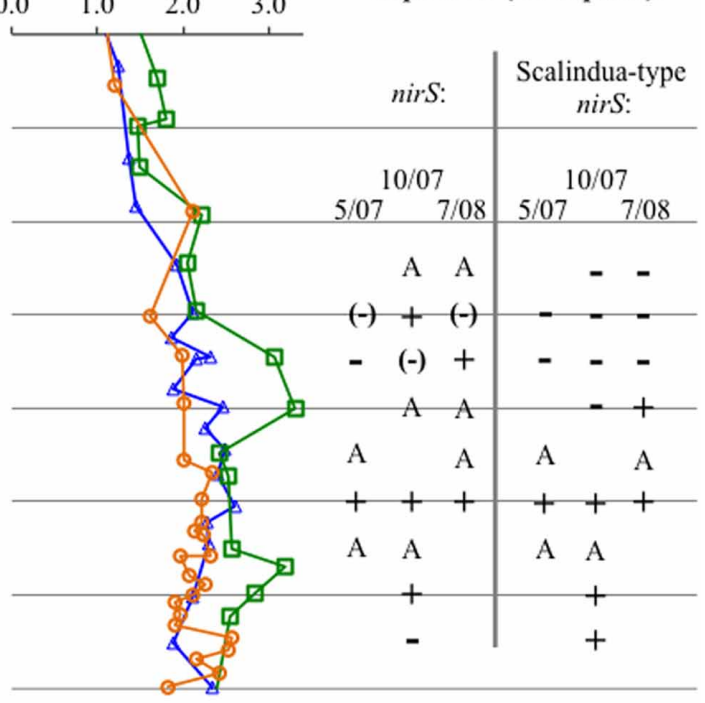

amplification without sequencing confirmation, while " + " indicates amplification and sequencing confirmation. " -" indicates no amplification, while " $(-)$ " indicates bands were apparent but sequencing resulted in non-specific sequences (generally, 23S ribosomal sequences). 
were highest in the sulfidic zone, but became negligible around $\sigma_{\theta}=16.0$ in October 2007 and July 2008 and at 15.8 in May 2007 (Figure 1). $\mathrm{N}_{2}$ supersaturation generally increased with depth and reached a broad maximum in the suboxic zone (Figure 2). $\mathrm{N}_{2}$ supersaturation was greatest in October 2007 with a maximum at $\sigma_{\theta}=15.7-15.8$.

Anammox and denitrifying mRNA transcripts were detected in all three sample sets (Figure 2). Note however, that deep RNA samples $\left(\sigma_{\theta}=16.2\right.$ and 16.3), extending into the sulfidic zone, were only available for October 2007. Considering first anammox, Scalindua-type nirS appeared localized to the lower suboxic zone $\left(\sigma_{\theta}=15.8\right)$, a distribution almost invariant for the time period sampled and coincident with a stable maxima in dissolved $\mathrm{N}_{2}$ (Figure 2). Four sequence groups were detected (Figure 3). Groups II and III were detected across a broad depth range (Figure 4), while group I was relatively shallow $(15.8 \leq$ $\left.\sigma_{\theta} \leq 16.0\right)$ and group IV was relatively deep $\left(16.0 \leq \sigma_{\theta} \leq 16.3\right)$. TRFLP of Scalindua 16S rDNA from May and October 2007

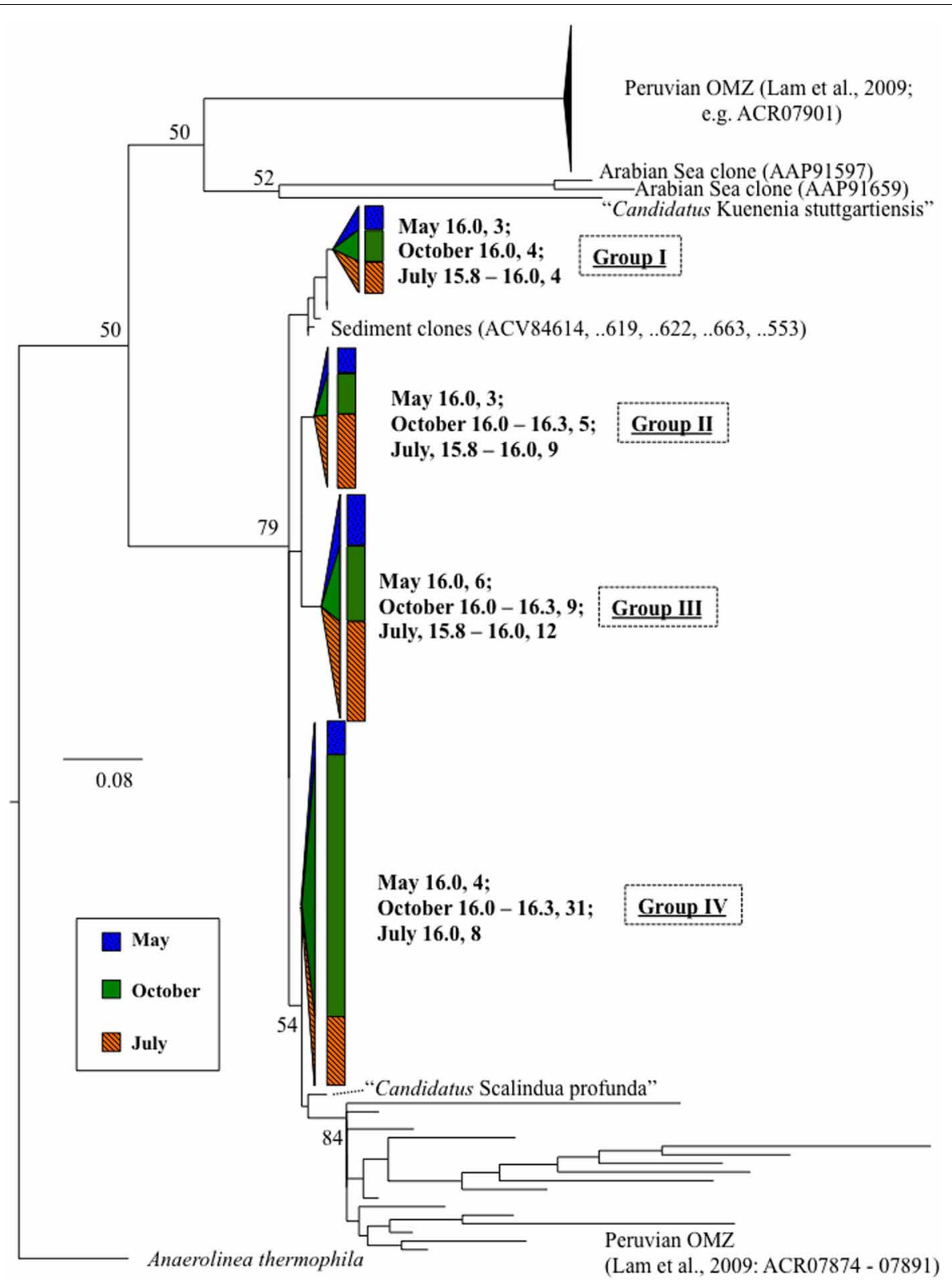

FIGURE 3 | Scalindua-type nirS expression, in bold, as detected with primers Scnir372F and Scnir845R (Lam et al., 2009). Numbers indicate density, followed by number of clones. References include cultured strains (in italics), and environmental clones. "Candidatus Scalindua" is from van de Vossenberg et al. (2012). Tree was constructed from amino acid sequences
( 160 aa), bootstrapped (100 replicates; nodes present $>50 \%$ noted) and analyzed for maximum likelihood phylogeny with Phylip (Felsenstein, 2005). Scale bar indicates branch length as calculated by protein maximum likelihood (Jones-Taylor-Thornton algorithm; Jones et al., 1992). Wedge and bar sizes are proportional to clone library composition. 


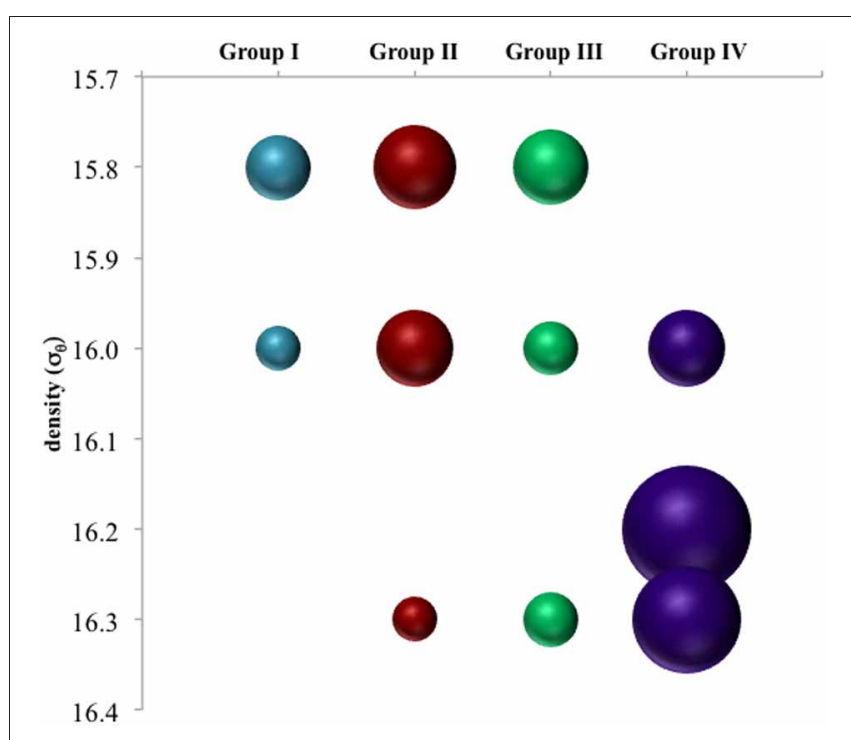

FIGURE 4 | Depth breakdown of groups noted in Figure 3. Area of bubbles are proportional to percentage of clone library sequences for a given depth found in a given group.

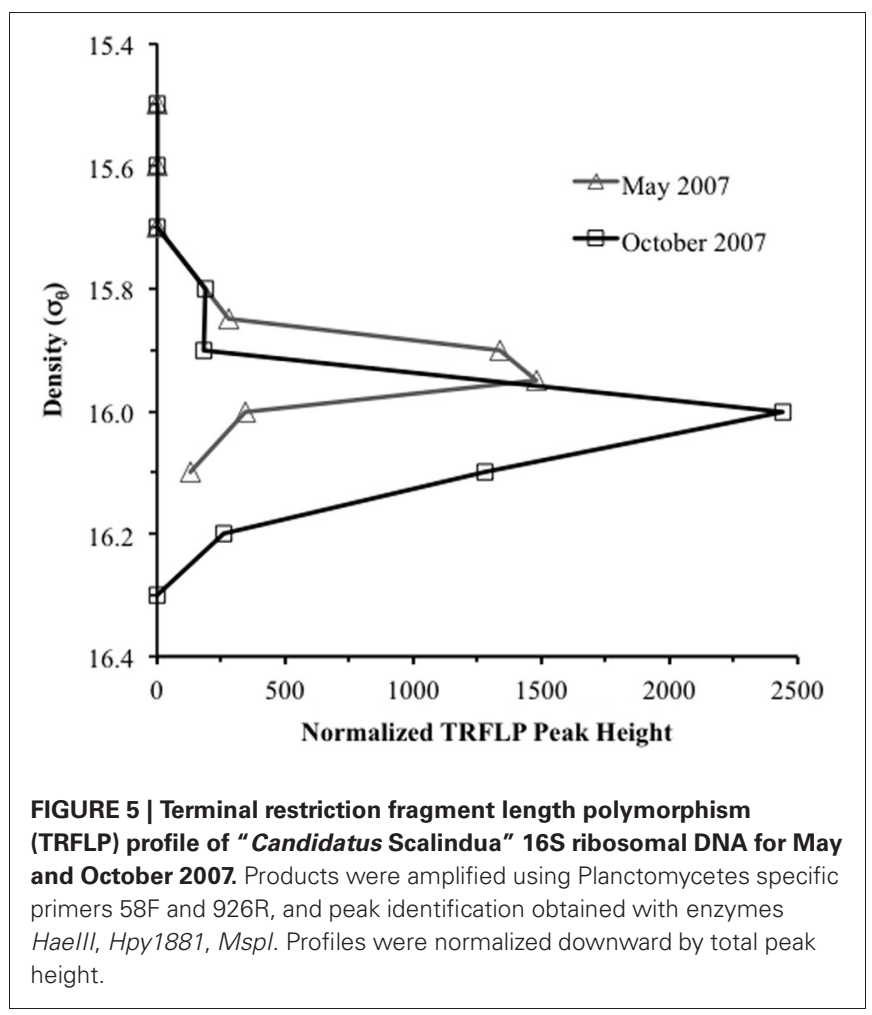

ranged from $\sigma_{\theta}=15.8$ to 16.2 with a maximum at $\sigma_{\theta}=15.95$ in May and $\sigma_{\theta}=16.0$ in October (Figure 5).

Conventional nirS expression was also continually present in the lower suboxic zone and continued into the upper sulfidic zone (Figure 2). Six major groups, as well as a variety of singletons, were found using the nirS1F/6R primer set and are labeled in Figure 6 for ease of discussion. Groups I, IV, and VI were expressed in a consistent pattern similar to anammox (Figure 7). Other groups and singletons were more dynamic, with varying depth ranges and/or seasons in which they were detected. Unlike anammox, however, some expression was detected in the upper suboxic zone $\left(\sigma_{\theta}=15.6,15.7\right.$; Figures 2, 7). Groups I, V, and VI were related to Baltic Sea samples (Hannig et al., 2006). Groups II and IV contained no closely related database sequences, while Group III had an Arabian Sea analog (Jayakumar et al., 2009b). Finally, Marinobacter hydrocarbonoclasticus was the sole described species closely related to sequences from these clone libraries.

Amplification with a second primer set for conventional nirS expression, cd3aF/R3cd (Throbäck et al., 2004), was only detected in the lower suboxic zone $\left(\sigma_{\theta} \geq 15.9\right)$. Groups I, III, and VI from the nirS1F/6R primer set results were also found with $\mathrm{cd} 3 \mathrm{aF} / \mathrm{R} 3 \mathrm{~cd}$

\section{(Figure 8).}

We used dissolved gases to estimate NCP in the surface mixed layer. NCP, effectively oxygen production in excess of consumption, was calculated from $\mathrm{O}_{2} / \mathrm{Ar}$ (Stanley et al., 2010; Figure 9A). NCP for the three cruises showed small but significant difference, with May 2007 and July 2008 having lower values (28 and $\left.26 \mathrm{mmol} \mathrm{O}_{2} \mathrm{~m}^{-2} \mathrm{~d}^{-1}\right)$ and October 2007 showing slightly elevated $\mathrm{NCP}\left(31 \mathrm{mmol} \mathrm{O}_{2} \mathrm{~m}^{-2} \mathrm{~d}^{-1}\right) . \delta^{18} \mathrm{O}-\mathrm{O}_{2}$ was also measured, which can show negative deviations if photosynthetic production is great enough to drive the below equilibrium levels (Quay et al., 1993). Unlike May 2007 and July 2008, October 2007 exhibited a large negative deviation in $\delta^{18} \mathrm{O}-\mathrm{O}_{2}$ immediately below the mixed layer, concordant with a $52 \%$ supersaturation of $\mathrm{O}_{2}$ relative to $\mathrm{Ar}$ (Ar used to normalize for physical processes; Figure 10).

\section{DISCUSSION}

\section{ANAMMOX-TYPE EXPRESSION}

Anammox-type nirS was first used as a process-specific sequence type in the Peruvian OMZ (Lam et al., 2009). All of the sequences amplified in this Black Sea study were monophyletic with Peruvian OMZ sequences, in turn closely allied to the environmental anammox clade, "Candidatus Scalindua" (Lam et al., 2009; van de Vossenberg et al., 2012) (Figure 3). For comparison, anammox-type $16 \mathrm{~S}$ rDNA was also analyzed (Figure 5). The observed distribution of this anammox-type nirS was consistent with this ribosomal DNA based distribution, as well as previous data sets (Kuypers et al., 2003; Kirkpatrick et al., 2006; Fuchsman et al., 2012). The presence of anammox bacteria in the lower suboxic zone may be due to the flux of ammonium from the sulfide zone that affects these depths. Although amplification of sequence types not involved in the anammox process cannot be ruled out, both the sequence data and depth distribution similarity lend credence to the applicability of these products as process specific markers.

Phylogenetically, expressed anammox-type nirS sequences fell into four highly similar groups (Figure 3). Distance between these Black Sea groups was less than between sequences from the Peruvian OMZ. It may be that a relatively small subset of marine anammox bacteria are adapted to the brackish waters of the Black Sea (suboxic zone salinity $\sim 20-21$ ) as compared to the Peruvian OMZ; this is consistent with previous 16S-based approaches (Schmid et al., 2007). 


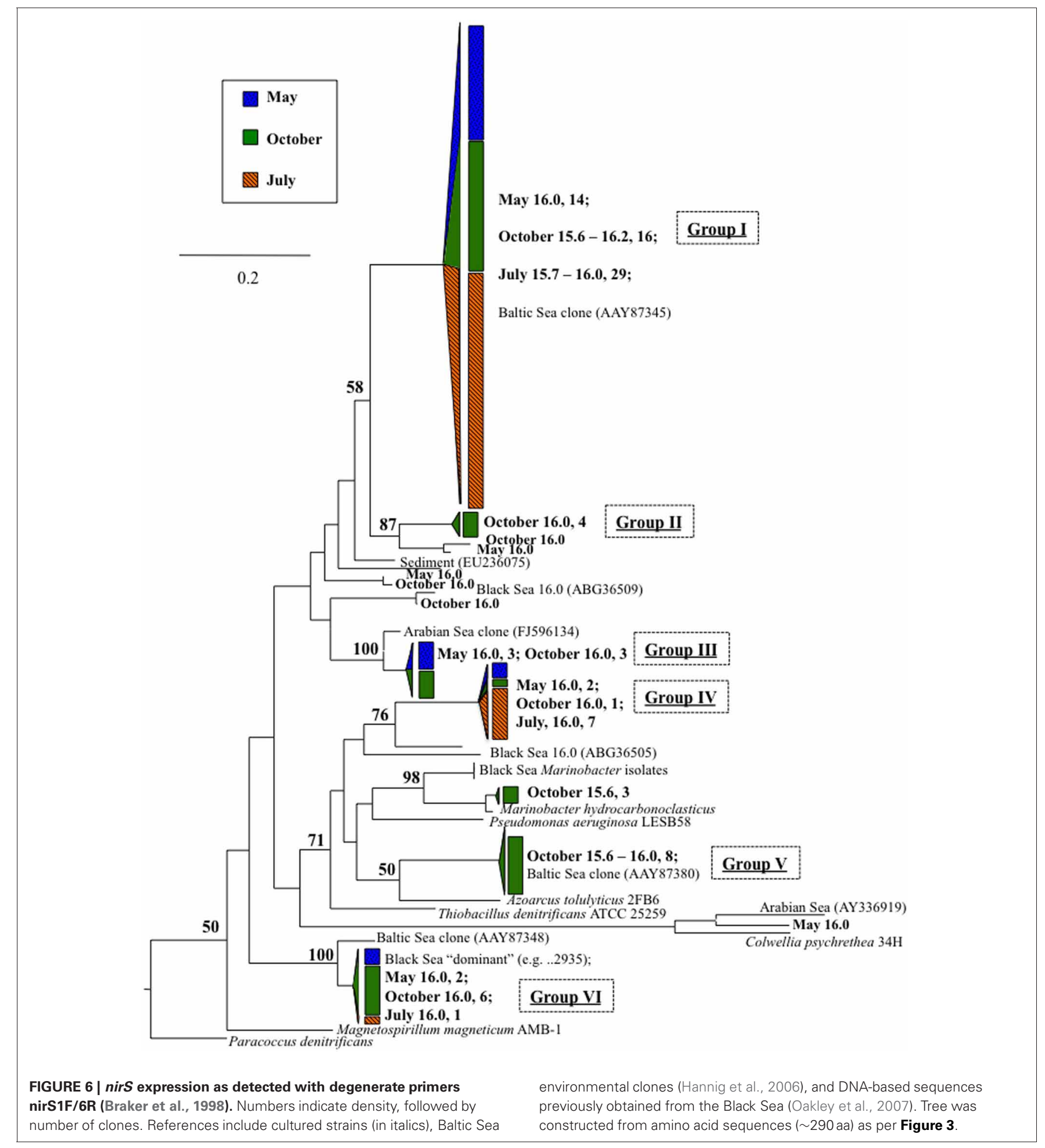

There appeared to be little difference between time points for the anammox-type nirS data, suggesting that these organisms were consistently transcribing this nirS-type gene. The single exception was July 2008, the only time that amplification could be detected as shallow as $\sigma_{\theta}=15.8$, though only a few sequences could be retrieved (Figure 2). This was also the time of shallowest oxygen penetration (Figure 1). Between groups, the only variation appeared to be associated with differences in depth. Group I expression was only detected for $15.8 \geq \sigma_{\theta} \geq 16.0$ and Group IV was found for $16.0 \geq \sigma_{\theta} \geq 16.3$; Groups II and III were found variously across the whole range (Figure 4). Interestingly, for the one sample set which extended into the sulfidic zone (October 


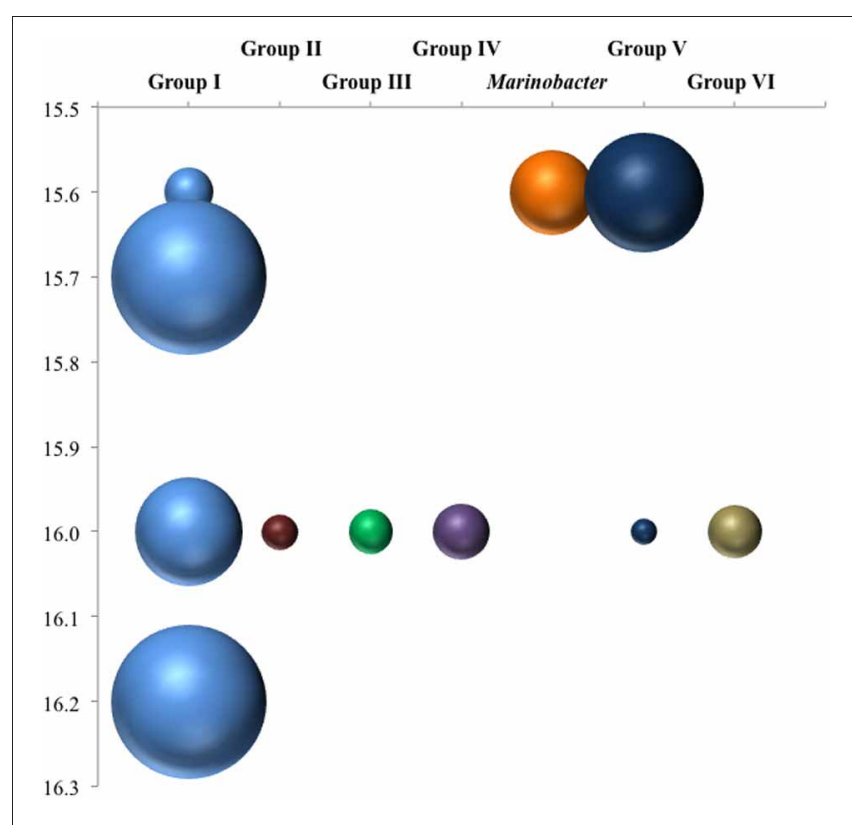

FIGURE 7 | Depth breakdown of groups noted in Figure 6. Areas of bubbles are proportional to percentage of clone library sequences for a given depth found in a given group.

2007) anammox activity could still be detected as deep as $\sigma_{\theta}=$ 16.3 , where $\mathrm{H}_{2} \mathrm{~S} \geq 10 \mu \mathrm{M}$. Evidence for the presence of anammox bacteria coincident with low levels of sulfide has been previously found in the Black Sea (Wakeham et al., 2007; Fuchsman et al., 2012). This suggests some sulfide tolerance for Groups II, III, and IV. Theoretically, these groups could be actively involved in S-linked processes (Kalyuzhnyi et al., 2006), provided that a flux of $\mathrm{NO}_{3}^{-}$or $\mathrm{NO}_{2}^{-}$penetrates down to these density surfaces. While this is speculative, it is known that $\mathrm{NO}_{2}^{-}$levels for $\sigma_{\theta} \geq 16.2$ were below the detection limit for October 2007, when deep activity was sampled (Figure 2). Other explanations for anammox activity require a supply of nitrite such as horizontal advection (Stunzhas and Yakushev, 2006) or in situ production with sparse oxidants such as trace levels of MnOx; a fast sinking mechanism to import active cells and their mRNA; or perhaps the utilization of abundant sulfate as the ultimate electron acceptor (Liu et al., 2008). While the specific adaptations of the four different anammox types are speculative, it is nonetheless apparent that there are some micro-heterogenities in this population.

\section{DENITRIFICATION AND RELATION TO ENVIRONMENTAL FACTORS}

Expression patterns of denitrification appeared more complex than anammox. October 2007 stands out in this data set due several factors, including deeper samples that were not available for the other two timepoints. Even excluding these samples, however, several "intermittent" groups were detected in October 2007 that were not found other times. Denitrifiers in the upper suboxic zone $\left(\sigma_{\theta}=15.6\right)$ were not only active, unlike other seasons, but included Marinobacter and Group V phylotypes not found at other times (Figures 6, 7). Group V contains sequences up to $100 \%$ similar to a sequence known from the Baltic Sea's upper, oxic waters (AAY87380; Hannig et al., 2006), suggesting a tolerance for relatively oxidizing conditions. The Marinobacter-type sequences were distinct from strains previously isolated from the Black Sea (bootstrap support 98\%) (Oakley et al., 2007). July 2008 also had transcripts at a relatively shallow density surface $\left(\sigma_{\theta}=15.7\right)$, but unlike the varied phylogeny of October 2007, the shallower July expression was only an extension of consistent, deeper Group I activity. This was perhaps in response to the shoaling of the oxycline (Figure 1).

Interestingly, October 2007 surface waters exhibited relatively high biological productivity (Figure 9A). October 2007 also had a large dissolved oxygen minimum below the mixed layer (Figure 10), suggestive of enhanced productivity, though assessing a rate to this deeper production is problematic. Although the linkage is indirect, if either mixed layer or deeper productivity resulted in sinking organic matter, this could have impacted heterotrophic denitrification. October 2007 was also unusual in the detection of elevated $\mathrm{N}_{2}$ supersaturation levels, indicative of biological $\mathrm{N}_{2}$ production, in both the upper suboxic zone $\left(15.6 \leq \sigma_{\theta} \leq 15.8\right)$ and the upper sulfidic layer $\left(16.1 \leq \sigma_{\theta} \leq\right.$ 16.25) (Figure 2). Part of this $\mathrm{N}_{2}$ build-up was potentially a result of these intermittently detected denitrifiers, particularly in the upper suboxic zone $\left(\sigma_{\theta}<15.8\right)$ where anammox type nirS expression was not found for our three time points. The deeper $\mathrm{N}_{2}$ peak $\left(\sigma_{\theta}=16.1-16.2\right)$ was found at the transition from suboxic to sulfidic zones, and nutrient profiles (Figure 1) are suggestive of deeper $\mathrm{H}_{2} \mathrm{~S}$ consumption in October; it is possible that autotrophic denitrification could also have been enhanced at this time.

Looking at the diversity of denitrifiers, the Shannon-Wiener index for the suboxic zone also peaked in October (Figure 9B; $\mathrm{H}_{\text {May }}^{\prime}=1.4, \mathrm{H}_{\text {Oct }}^{\prime}=1.9, \mathrm{H}_{\text {Jul }}^{\prime}=0.6$ ). This is excluding the deep samples unique to the October cruise. In October, when the $\mathrm{N}_{2}$ build-up had both a shallow and a deep peak (Figure 2), $\sigma_{\theta}=$ 15.6 in the upper suboxic zone had some nirS expression not seen other times (Figure 7), in addition to the consistent deep expression. This multiplicity of apparent niches was one of the drivers of diversity in October. If in fact greater productivity led to C export which stimulated denitrification at depth, this would be consistent with other studies that have linked organic $\mathrm{C}$ input to changes in denitrification activity (Engström et al., 2005; Fuchsman et al., 2008; Ward et al., 2008, 2009).

Many denitrifier groups, on the other hand, seem more similar to the detected anammox expression in that their expression was detected regularly between seasons and in the lower suboxic zone. These "consistent" denitrifiers include an unknown type (Group IV), a Group that was previously known from Black Sea clone libraries as the "dominant" type (Oakley et al., 2007)-here, Group VI-and a third type (Group I) identical to a different Baltic Sea clone, this one from suboxic waters (AAY87345; Hannig et al., 2006). Transcripts of this Baltic Sea type were found into the sulfidic layer. Whether this represents autotrophic or heterotrophic denitrification is unknown. While there were some sequences shared with Baltic Sea studies, it is notable that the consistent expression pattern typical of Black Sea groups I, IV, and VI discussed here are different from the temporal changes documented in the Baltic Sea (Hannig et al., 2007). 


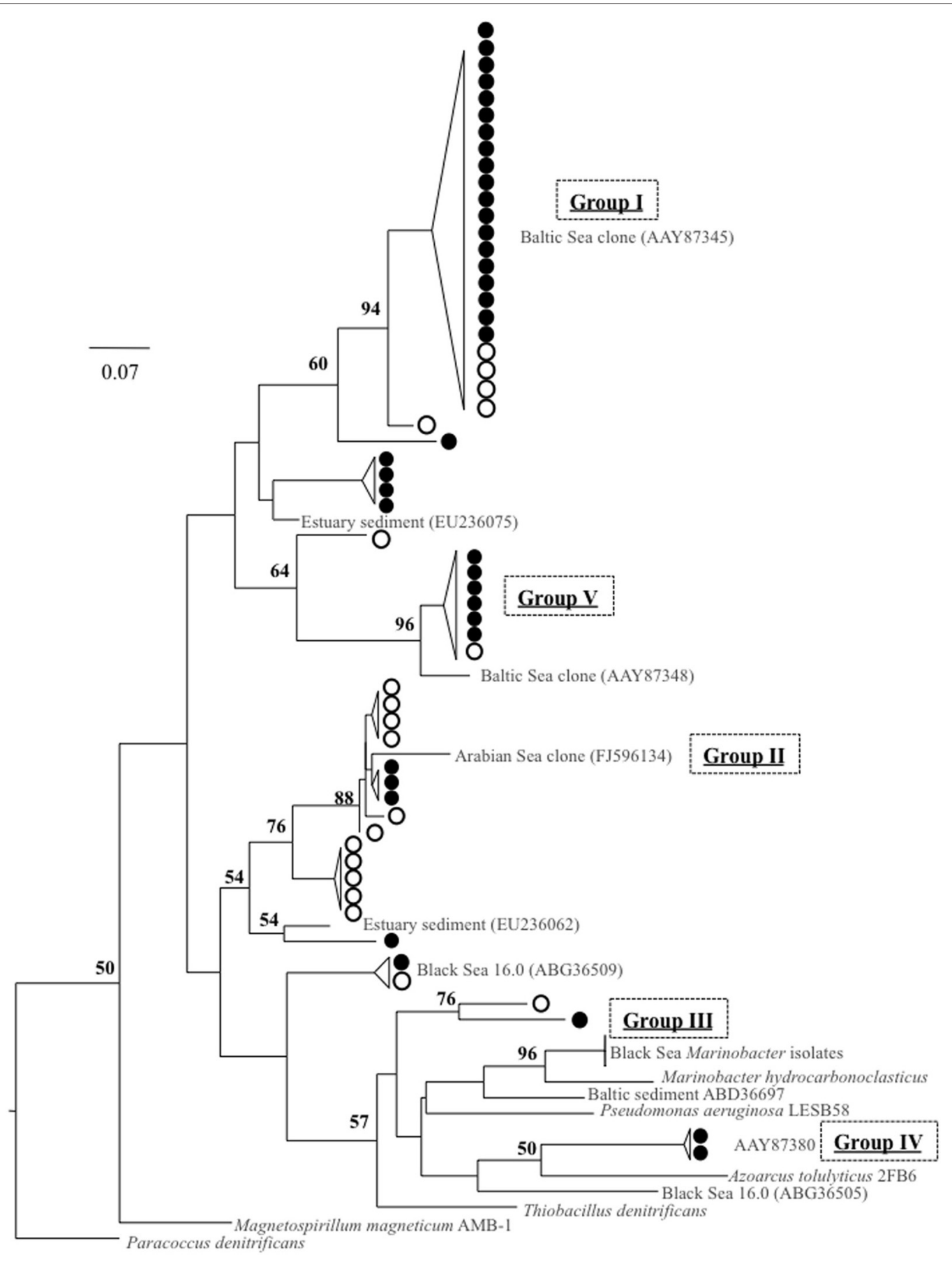

FIGURE 8 | Clone library comparison tree for two different primer pairs: nirS1F/6R, indicated by filled circles, and cd3aF/R3cd, in empty circles. All are from October $2007, \sigma_{\theta}=16.0$ or 16.2 . References, in gray, include cultured strains (in italics), Baltic Sea environmental clones (Hannig et al.,
2006), and DNA-based sequences previously obtained from the Black Sea (Oakley et al., 2007). Tree was constructed from amino acid sequences ( 140 aa, necessarily shorter than other alignments) as per Figure 3
Denitrification was indicated in the Baltic mainly in instances where the suboxic zone was compressed or absent and nitrate and sulfide overlapped, with the establishment of a stable suboxic zone favoring anammox (Hannig et al., 2007). Measurable levels of nitrate and sulfide do not commonly overlap in the Black
Sea (Murray et al., 1995), though as noted above and in Figure 1 some variability was observed in this study. Several lines of published evidence point toward autotrophic metabolism by $\varepsilon$ - and $\gamma$-proteobacteria in the sulfidic zone, including the autotrophic denitrifier Sulfurimonas (Grote et al., 2008; Glaubitz et al., 2010). 


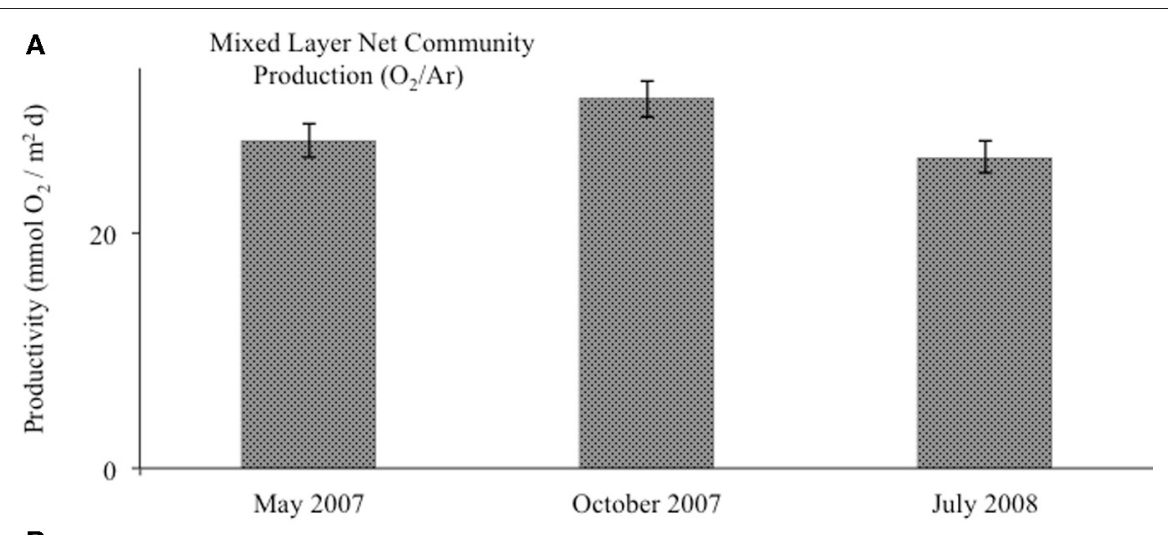

$\mathbf{B}$

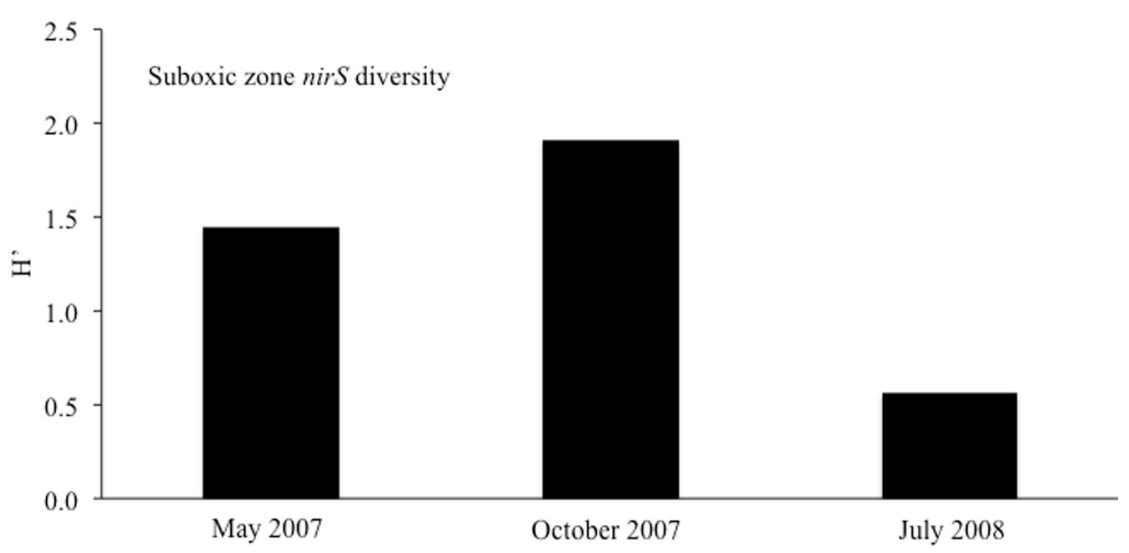

FIGURE 9 | (A) For the surface mixed layer, net community productivity calculated with $\mathrm{O}_{2} /$ Ar measurements. Error bars for NCP were calculated from averages of mixed layer $\mathrm{O}_{2} / \operatorname{Ar}(n=4)$. (B) Suboxic zone $\left(15.6 \leq \sigma_{\theta} \leq 16.0\right)$ clone library diversity, as calculated with the Shannon-Wiener index.

In the case of Sulfurimonas, primer mismatch could have prevented detection of mRNA transcripts by our methods; see primer bias considerations, below.

\section{CONCURRENT DENITRIFICATION AND ANAMMOX ACTIVITY}

Both denitrification and anammox type nirS expression were consistently detected at the same density surfaces in the lower suboxic zone. This occurs despite the fact that they have different metabolic requirements, and in spite of the restricted, relatively stable environment formed by the redox gradient; this seems to indicate that conditions are conducive for both processes to persist simultaneously. As both require nitrite, a competitive playoff between the two processes is often assumed (e.g., Hannig et al., 2007; Bulow et al., 2010; Lam et al., 2011). Our data set suggests that this may not be the case, with the ongoing activity of both processes more similar to the balanced activity seen in Skagerrak sediments (Thamdrup and Dalsgaard, 2002) or the waters of Golfo Dulce (Dalsgaard et al., 2003).

\section{PRIMER BIAS CONSIDERATIONS}

Regarding primer sets, it should be noted that the nirS primer set used here (nirS1F/nirS6R), while degenerate, is not considered universal (Throbäck et al., 2004). Nitrite reductase genes, here focusing on nirS, are fairly diverse and exhibit significant sequence divergence, making whole-community analysis difficult and subject to bias. A fairly comprehensive analysis of different primer sets was conducted in 2004 for cultured organisms and soil samples (Throbäck et al., 2004). Studies of ocean OMZs have commonly relied on nirS1F/6R (Braker et al., 1998) or cd3aF/R3cd (Michotey et al., 2000; Throbäck et al., 2004). In order to assess possible primer pair bias in our data sets, products of both primer sets were analyzed. It must be noted that while we could compare between primer sets and samples, it is difficult to infer what other potential sequences were missed entirely. There could have been a large number of organisms contributing to the mRNA pool that remained undetected due to primer mismatches, including Sulfurimonas, which has previously been detected in the Black Sea (Grote et al., 2008). Compared to the Braker primers (Braker et al., 1998), we found Sulfurimonas denitrificans DSM1 to have 6 mismatches and one deletion over the 18 bp of nirS1F and 10 mismatches over the 16 bp of nirS6R. Regardless of what was missed, given the data at hand it was possible to compare data produced by these two primer sets in an effort to understand what relative biases may have been present.

While nirS1F/6R amplified sequences throughout the suboxic zone, albeit intermittently for the upper suboxic zone (Figure 2), $\mathrm{cd} 3 \mathrm{aF} / \mathrm{R} 3 \mathrm{~cd}$ amplification was only successful in the lower suboxic zone $\left(\sigma_{\theta} \geq 15.9\right)$. This suggests that the upper suboxic zone community may be "missed" not only because of changes in activity but also due to poor amplification if analyzed with a different 


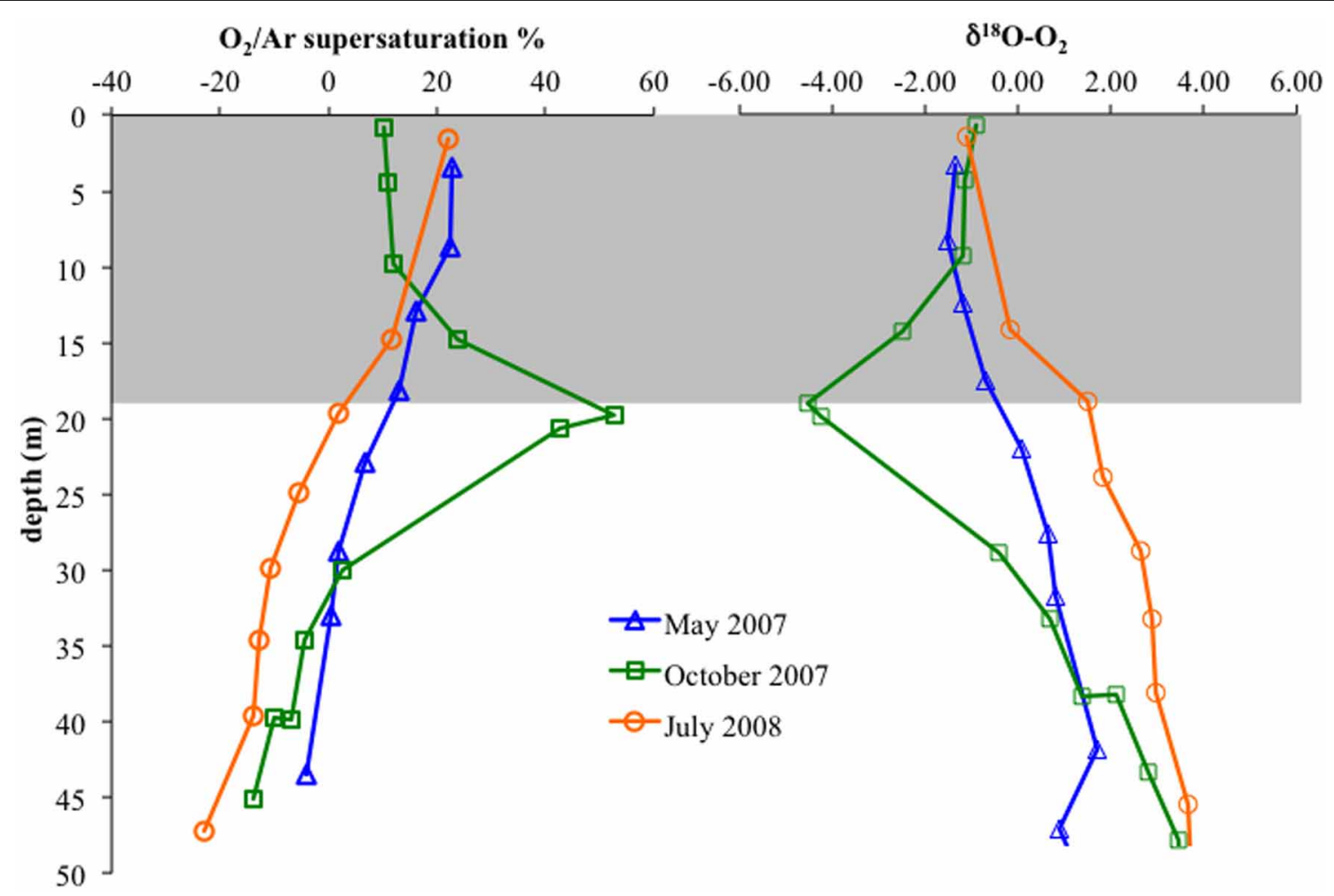

FIGURE 10 | Left: $\mathrm{O}_{2} / \mathrm{Ar}$ supersaturation versus depth in the upper $50 \mathrm{~m}$ for May 2007, October 2007, and July 2008. Right: $\delta^{18} \mathrm{O}-\mathrm{O}_{2}$ versus depth. Gray box indicates average mixed layer depths.

primer set. This was further indicated by analyzing the entire nirS1F/6R data set (all depths) for mismatches to the $\mathrm{cd} 3 \mathrm{aF} / \mathrm{R} 3 \mathrm{~cd}$ priming site, both of which are internal to the amplicon produced by nirS1F/6R. 73\% of nirS1F/6R clones mismatched the cd3aF primer, and 99\% mismatched R3cd. The same analysis for nirS1F or $6 \mathrm{R}$ binding sites is not possible, as both sites are outside of the amplicons produced by $\mathrm{cd} 3 \mathrm{aF} / \mathrm{R} 3 \mathrm{~cd}$.

In order to check for systematic discrimination of specific phyla by the different primer sets, sequences of both for October samples $\sigma_{\theta}=16.0$ and 16.2 were obtained (Figure 8). It is important to note that ribosomal contamination was intermittently found in both data sets. This contamination, typically found in the absence of nirS template, was detected when sequences contained multiple stop codons and could not be aligned; it was confirmed with BLAST searches to the Genbank database. For nirS1F/6R this only happened in the upper suboxic zone. This was true even when bands of the proper size were excised and purified from the agarose gel and even when, additionally, mRNA purification of the RNA extract (MICROBExpress ${ }^{\odot}$, Ambion) was conducted before reverse transcription. This suggests that qPCR methods cannot be easily applied to these primer sets. Considering phylogeny, groups I, II, and V were present in both data sets, suggesting fairly good overlap between primer products (Figure 8). While it is not easy to make conclusions about groups that were not present, due to sampling depth, overall diversity of the two different data sets is similar (Shannon-Wiener index of 1.6 for 1F/6R, 1.8 for cd3aF/R3cd). In summary, while no clade-specific bias appeared when comparing sequences from successfully amplified PCR products of both primer sets for the same depths, for other depths nirS1F/6R was the only primer set that produced any nirS-type sequences at all. This suggests that, for some marine environments such as OMZs, $c d 3 a F / R 3 c d$ may undersample diversity.

\section{CONCLUSIONS}

Our results, based on analysis of dissimilatory nitrite reductase (nirS) expression over three sampling seasons, revealed that both denitrification and anammox were consistently found in the lower suboxic zone, for three sample sets spanning 15 months. Consistent nirS-expression was localized to the lower suboxic zone, and included both anammox and conventional denitrification type genes. Intermittent nirS expression was detected in the upper suboxic zone $\left(\sigma_{\theta} \leq 15.7\right)$ and varied between sampling times, perhaps in response to environmental variables such as oxygen and organic $\mathrm{C}$ input. This connection is inferred, and not proven; other studies are required to directly investigate this linkage. The fluctuating response of some denitrifiers appears not just the opportunistic response of phylotypes otherwise routinely active at other depths, but characteristic of several groups that were not found to be active at other times, within the acknowledged limitations of sampling and sequencing for this study. This underscores the problematic nature of making global $\mathrm{N}$ budgets based on instantaneous measurements of rate or activity, and points toward the necessity of time-integrated approaches in 
order to resolve conflicting estimates. Further work is needed to directly examine the interplay between surface productivity and deeper denitrification, resolve inconsistencies between methods based on in situ parameters versus incubations, and to understand the ongoing activity and interplay of anammox, heterotrophic denitrification, and autotrophic denitrification.

\section{ACKNOWLEDGMENTS}

This work was supported by grants NSF OCE-0751617, NSF IGERT 05-04219, NSF OISE 0637845, NSF OISE 0637866, and
CRDF GCP-15123. The May 2007 cruise was also supported by the Lewis and Clark Astrobiology Travel Grant to Clara A. Fuchsman. We thank the staff of the Laboratory of Marine Chemistry of the Southern Branch of Shirshov Institute of Oceanology RAS (Ghelendzhik). We are indebted to Barbara Paul for essential aid in field and laboratory work, as well as Alexander Novigatsky, Alexander Filippov, Alexander Egorov, Nikolay Pimenov, and Oleg Podymov for help collecting samples. Thank you to Paul Quay, Steve Emerson, and Eric Steig for use of lab space and equipment.

\section{REFERENCES}

Altabet, M. A., Francois, R., Murray, D. W., and Prell, W. L. (1995). Climate-related variations in denitrification in the Arabian Sea from sediment $15 \mathrm{~N} / 14 \mathrm{~N}$ ratios. Nature 373, 506-509.

Altabet, M. A., Murray, D. W., and Prell, W. L. (1999). Climatically linked oscillations in Arabian Sea denitrification over the past 1 m.y.: implications for the marine $\mathrm{N}$ cycle. Paleoceanography 14, 732-743.

Braker, G., Fesefeldt, A., and Witzel, K. P. (1998). Development of PCR primer systems for amplification of nitrite reductase genes (nirK and nirS) to detect denitrifying bacteria in environmental samples. Appl. Environ. Microbiol. 64, 3769-3775.

Bulow, S. E., Rich, J. J., Naik, H. S., Pratihary, A. K., and Ward, B. B. (2010). Denitrification exceeds anammox as a nitrogen loss pathway in the Arabian Sea oxygen minimum zone. Deep-Sea Res. 57(Pt 1), 384-393.

Dalsgaard, T., Canfield, D. E., Petersen, J., Thamdrup, B., and AcuñaGonzález, J. (2003). N2 production by the anammox reaction in the anoxic water column of Golfo Dulce, Costa Rica. Nature 422, 606-608.

Emerson, S., Stump, C., Wilbur, D. O., and Quay, P. (1999). Accurate measurement of $\mathrm{O}_{2}, \mathrm{~N}_{2}$, and Ar gases in water and the solubility of $\mathrm{N}_{2}$. Mar. Chem. 64, 337-347.

Engström, P., Dalsgaard, T., Hulth, S., and Aller, R. C. (2005). Anaerobic ammonium oxidation by nitrite (anammox): implications for $\mathrm{N}_{2}$ production in coastal marine sediments. Geochim. Cosmochim. Acta 69, 2057-2065.

Felsenstein, J. (1989). PHYLIP Phylogeny Inference Package (Version 3.2). Cladistics 5, 164-166.

Fuchsman, C. A., Murray, J. W., and Konovalov, S. K. (2008). Concentration and natural stable isotope profiles of nitrogen species in the Black Sea. Mar. Chem. 111, 90-105.

Fuchsman, C. A., Staley, J. T., Oakley, B. B., Kirkpatrick, J. B., and Murray, J. W. (2012). Freeliving and aggregate-associated Planctomycetes in the Black Sea. FEMS Microbiol. Ecol. 80, 402-416.

Ganeshram, R. S., Pedersen, T. F., Calvert, S. E., and Murray, J. W. (1995). Large changes in oceanic nutrient inventories from glacial to interglacial periods. Nature 376 , 755-758.

Glaubitz, S., Labrenz, M., Jost, G., and Jürgens, K. (2010). Diversity of active chemolithoautotrophic prokaryotes in the sulfidic zone of a Black Sea pelagic redoxcline as determined by rRNA-based stable isotope probing. FEMS Microbiol. Ecol. 74, 32-41.

Grasshoff, K., Ehrhardt, M., and Kreming, K. (eds). (1983). Methods of Seawater Analysis. Third comp. Weinheim/New York/ Chichester/Brisbane/Singapore/Tor onto: Wiley-VCH.

Grote, J., Jost, G., Labrenz, M., Herndl, G. J., and Jürgens, K. (2008). Epsilonproteobacteria represent the major portion of chemoautotrophic bacteria in sulfidic waters of pelagic redoxclines of the Baltic and Black Seas. Appl. Environ. Microbiol. 74, 7546-7551.

Hannig, M., Braker, G., Dippner, J., and Jürgens, K. (2006). Linking denitrifier community structure and prevalent biogeochemical parameters in the pelagial of the central Baltic Proper (Baltic Sea). FEMS Microbiol. Ecol. 57, 260-271.

Hannig, M., Lavik, G., Kuypers, M. M. M., Woebken, D., MartensHabbena, W., and Jürgens, K. (2007). Shift from denitrification to anammox after inflow events in the central Baltic Sea. Limnol. Oceanogr. 52, 1336-1345.

Jayakumar, A., O’Mullan, G. D., Naqvi, S. W. A., and Ward, B. B. (2009a).
Denitrifying bacterial community composition changes associated with stages of denitrification in oxygen minimum zones. Microb. Ecol. 58, 350-362.

Jayakumar, A., Naqvi, S. W. A., and Ward, B. B. (2009b). Distribution and relative quantification of key genes involved in fixed nitrogen loss from the Arabian Sea oxygen minimum zone. Geophs. Monogr. Ser. 185, 187-203.

Jensen, M. M., Kuypers, M. M. M., Lavik, G., and Thamdrup, B. (2008). Rates and regulation of anaerobic ammonium oxidation and denitrification in the Black Sea. Limnol. Oceanogr. 53, 23-36.

Jensen, M. M., Lam, P., Revsbech, N. P., Nagel, B., Gaye, B., Jetten, M. S. M., and Kuypers, M. M. M. (2011). Intensive nitrogen loss over the Omani Shelf due to anammox coupled with dissimilatory nitrite reduction to ammonium. ISME J. 5, 1660-1670.

Jones, D. T., Taylor, W. R., and Thornton, J. M. (1992). The rapid generation of mutation data matrices from protein sequences. Comput. Appl. Biosci. 8, 275-282.

Kalyuzhnyi, S., Gladchenko, M. Mulder, A., and Versprille, B. (2006). DEAMOX-new biological nitrogen removal process based on anaerobic ammonia oxidation coupled to sulphide-driven conversion of nitrate into nitrite. Water Res. 40 , 3637-3645.

Kirkpatrick, J. B., Oakley, B. B., Fuchsman, C. A., Srinivasan, S., Staley, J. T., and Murray, J. W. (2006). Diversity and distribution of Planctomycetes and related bacteria in the suboxic zone of the Black Sea. Appl. Environ. Microbiol. 72, 3079-3083.

Kuypers, M. M. M., Sliekers, A. O., Lavik, G., Schmid, M., Jørgensen, B. B., Kuenen, J. G., Sinninghe Damsté, J. S., Strous, M., and Jetten, M. S. M. (2003). Anaerobic ammonium oxidation by anammox bacteria in the Black Sea. Nature 422, 608-611.
Lam, P., Jensen, M. M., Lavik, G., McGinnis, D. F., Müller, B., Schubert, C. J., Amann, R., Thamdrup, B., and Kuypers, M. M. M. (2007). Linking crenarchaeal and bacterial nitrification to anammox in the Black Sea. Proc. Natl. Acad. Sci. U.S.A. 104, 7104-7109.

Lam, P., Lavik, G., Jensen, M. M., van de Vossenberg, J., Schmid, M., Woebken, D., Gutiérrez, D., Amann, R., Jetten, M. S. M., and Kuypers, M. M. M. (2009). Revising the nitrogen cycle in the Peruvian oxygen minimum zone. Proc. Natl. Acad. Sci. U.S.A. 106, 4752-4757.

Lam, P., Jensen, M. M., Kock, A., Lettmann, K. A., Plancherel, Y., Lavik, G., Bange, H. W., and Kuypers, M. M. M. (2011). Origin and fate of the secondary nitrite maximum in the Arabian Sea. Biogeosciences 8, 1565-1577.

Liu, S., Yang, F., Gong, Z., Meng, F., Chen, H., Xue, Y., and Furukawa, K. (2008). Application of anaerobic ammonium-oxidizing consortium to achieve completely autotrophic ammonium and sulfate removal. Bioresour. Technol. 99, 6817-6825.

Michotey, V., Méjean, V., and Bonin, P. (2000). Comparison of methods for quantification of cytochrome $\mathrm{cd}(1)$-denitrifying bacteria in environmental marine samples. Appl. Environ. Microbiol. 66, 1564-1571.

Murray, J. W., Codispoti, L. A., and Friedrich, G. E. (1995). “Oxidationreduction environments: the suboxic zone in the Black Sea," in Aquatic Chemistry: Interfcial and Interspecies Processess, eds C. P., Huang, C. R. O'Melia, and J. J. Morgan (San Francisco, CA: American Chemical Society), 157-176.

Nicholson, D., Emerson, S., Caillon, N., Jouzel, J., and Hamme, R. C. (2010). Constraining ventilation during deepwater formation using deep ocean measurements of the dissolved gas ratios $40 \mathrm{Ar} / 36 \mathrm{Ar}$, $\mathrm{N} 2$ /Ar, and Kr/Ar. J. Geophys. Res. 115, C11015. 
Nightingale, P. D., Malin, G., Law, C. S., Watson, A. J., Liss, P. S., Liddicoat, M. I., Boutin, J., and UpstillGoddard, R. C. (2000). In situ evaluation of air-sea gas exchange parameterizations using novel conservative and volatile tracers. Glob. Biogeochem. Cycles 14, 373-387.

Oakley, B. B., Francis, C. A., Roberts, K. J., Fuchsman, C. A., Srinivasan, S., and Staley, J. T. (2007). Analysis of nitrite reductase (nirK and nirS) genes and cultivation reveal depauperate community of denitrifying bacteria in the Black Sea suboxic zone. Environ. Microbiol. 9, 118-130.

Poretsky, R. S., Bano, N., Buchan, A., Lecleir, G., Kleikemper, J., Pickering, M., Pate, W. M., Moran, M. A., and Hollibaugh, J. T. (2005). Analysis of microbial gene transcripts in environmental samples. Appl. Environ. Microbiol. 71, 4121-4126.

Quay, P. D., Emerson, S., Wilbur, D. O., Stump, C., and Knox, M. (1993). The $\delta^{18} \mathrm{O}$ of dissolved $\mathrm{O}_{2}$ in the surface waters of the subarctic Pacific: a tracer of biological productivity. J. Geophys. Res. 98, 8447-8458.

Santoro, A. E., Boehm, A. B., and Francis, C. A. (2006). Denitrifier community composition along a nitrate and salinity gradient in a coastal aquifer. Appl. Environ. Microbiol. 72, 2102-2109.

Schmid, M. C., Risgaard-Petersen, N., van de Vossenberg, J., Kuypers, M.
M., Lavik, G., Petersen, J., Hulth, S., Thamdrup, B., Canfield, D., Dalsgaard, T., Rysgaard, S., Sejr, M. K., Strous, M., den Camp, H. J., and Jetten, M. S. (2007). Anaerobic ammonium-oxidizing bacteria in marine environments: widespread occurrence but low diversity. Environ. Microbiol. 9, 1476-1484.

Stanley, R. H. R., Kirkpatrick, J. B., Cassar, N., Barnett, B. A., and Bender, M. L. (2010). Net community production and gross primary production rates in the western equatorial Pacific. Glob. Biogeochem. Cycles 24, 1-17.

Stunzhas, P. A., and Yakushev, E. V. (2006). Fine hydrochemical structure of the redox zone in the black sea according to the results of measurements with an open oxygen sensor and with bottle samplers. Oceanology 46, 629-641.

Thamdrup, B., and Dalsgaard, T. (2002). Production of $\mathrm{N}_{2}$ through anaerobic ammonium oxidation coupled to nitrate reduction in marine sediments. Appl. Environ. Microbiol. 68, 1312-1318.

Throbäck, I. N., Enswall, K., Jarvis, Å., and Hallin, S. (2004). Reassessing PCR primers targeting nirS, nirK and nosZ genes for community surveys of denitrifying bacteria with DGGE. FEMS Microbiol. Ecol. 49, 401-417.

van de Vossenberg, J., Woebken, D., Maalcke, W. J., Wessels, H. J.,
Dutilh, B. E., Kartal, B., JanssenMegens, E. M., Roeselers, G., Yan, J., Speth, D., Gloerich, J., Geerts, W., van der Biezen, E., Pluk, W., Francoijs, K. J., Russ, L., Lam P., Malfatti, S. A., Tringe, S. G., Haaijer, S. C., Op den Camp, H. J., Stunnenberg, H. G., Amann, R., Kuypers, M. M., and Jetten, M. S. (2012). The metagenome of the marine anammox bacterium "Candidatus Scalindua profunda" illustrates the versatility of this globally important nitrogen cycle bacterium. Environ. Microbiol. doi: 10.1111/j.1462-2920.2012.02774.x. [Epub ahead of print].

Wakeham, S. G., Amann, R., Freeman, K., Hopmans, E., Jørgensen, B. B., Putnam, I., Schouten, S., Sinninghedamste, J., Talbot, H., and Woebken, D. (2007). Microbial ecology of the stratified water column of the Black Sea as revealed by a comprehensive biomarker study. Org. Geochem. 38, 2070-2097.

Wang, J., Jenkins, C., Webb, R. I. and Fuerst, J. A. (2002). Isolation of Gemmata-Like and IsosphaeraLike Planctomycete Bacteria from Soil and Freshwater. Appl. Environ. Microbiol. 68, 417-422.

Ward, B. B., Tuit, C., Jayakumar, A., Rich, J. J., Moffett, J., Wajih, S., and Naqvi, A. (2008). Organic carbon, and not copper, controls denitrification in oxygen minimum zones of the ocean. Deep-Sea Res. 55(Pt I), 1672-1683.
Ward, B. B., Devol, A. H., Rich, J. J., Chang, B. X., Bulow, S. E., Naik, H. S., Pratihary, A. K., and Jayakumar, A. (2009). Denitrification as the dominant nitrogen loss process in the Arabian Sea. Nature 461, 78-81.

Conflict of Interest Statement: The authors declare that the research was conducted in the absence of any commercial or financial relationships that could be construed as a potential conflict of interest.

Received: 14 February 2012; accepted: 29 June 2012; published online: 19 July 2012.

Citation: Kirkpatrick JB, Fuchsman CA, Yakushev E, Staley JT and Murray JW (2012) Concurrent activity of anammox and denitrifying bacteria in the Black Sea. Front. Microbio. 3:256. doi: 10.3389/fmicb.2012.00256

This article was submitted to Frontiers in Aquatic Microbiology, a specialty of Frontiers in Microbiology.

Copyright (c) 2012 Kirkpatrick, Fuchsman, Yakushev, Staley and Murray. This is an open-access article distributed under the terms of the Creative Commons Attribution License, which permits use, distribution and reproduction in other forums, provided the original authors and source are credited and subject to any copyright notices concerning any third-party graphics etc. 